US Army Corps

of Engineers ${ }_{\circledast}$

Engineer Research and

Development Center

Ecosystem Management and Restoration Research Program

\title{
A Review of Coastal Vulnerability Assessments: Definitions, Components, and Variables
}

Christine VanZomeren and Damarys Acevedo-Mackey

June 2019

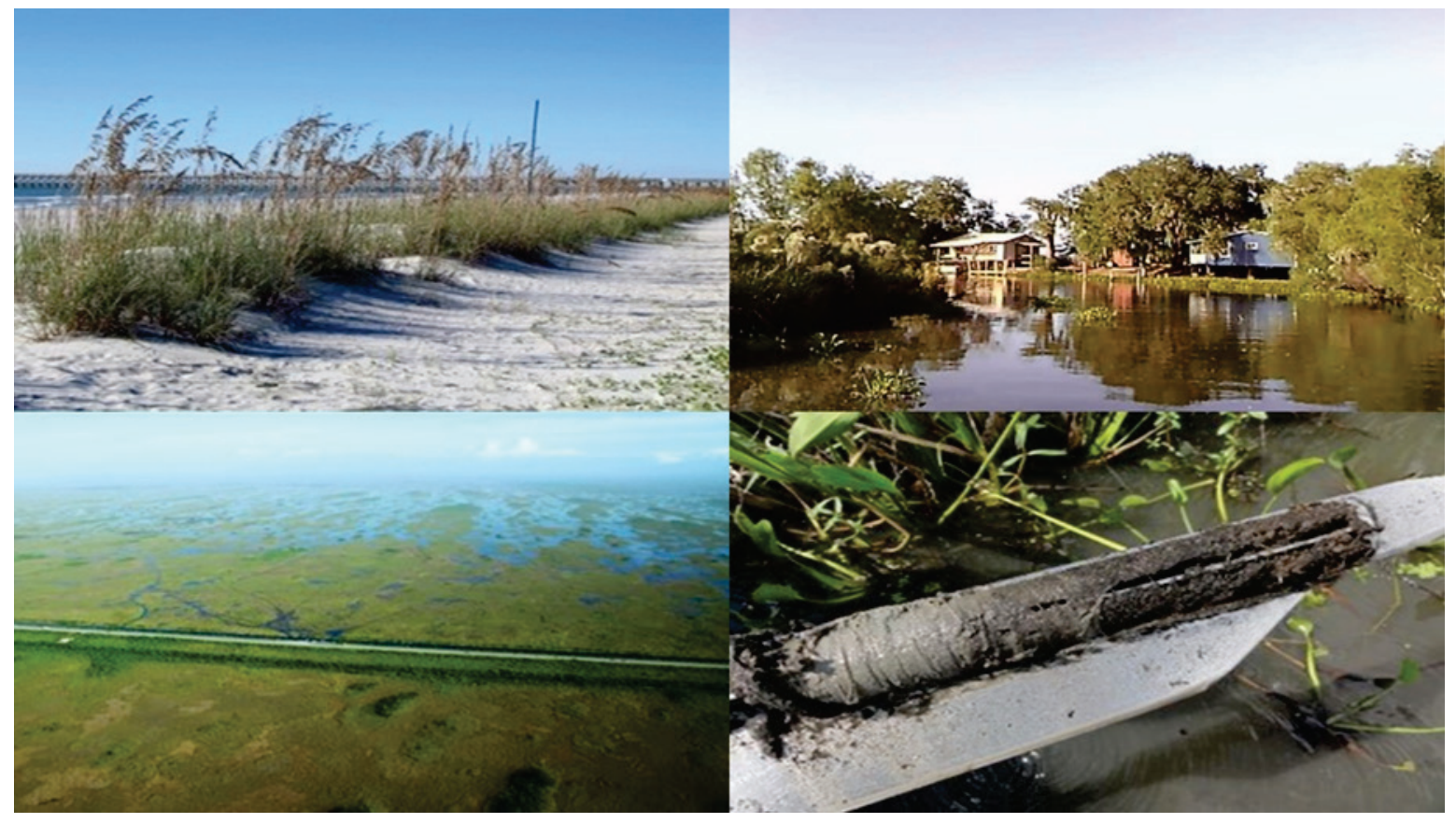


The U.S. Army Engineer Research and Development Center (ERDC) solves the nation's toughest engineering and environmental challenges. ERDC develops innovative solutions in civil and military engineering, geospatial sciences, water resources, and environmental sciences for the Army, the Department of Defense, civilian agencies, and our nation's public good. Find out more at www.erdc.usace.army.mil.

To search for other technical reports published by ERDC, visit the ERDC online library at https://erdc-library.erdc.dren.mil. 


\section{A Review of Coastal Vulnerability Assessments: Definitions, Components, and Variables}

Christine VanZomeren and Damarys Acevedo-Mackey

Environmental Laboratory

U.S. Army Engineer Research and Development Center

3909 Halls Ferry Rd.

Vicksburg, MS 39180

Final Report

Approved for public release; distribution is unlimited.

Prepared for Headquarters, U.S. Army Corps of Engineers

Washington, DC 20314-1000

Under Project Number2016-ER-5 


\section{Abstract}

Coastal zones are dynamic environmental systems providing an interface between land and sea. Coastal zones are also dynamic socioeconomic systems that support concentrated populations and critical infrastructure. Coastal features provide an array of ecological services including wildlife habitat, carbon sequestration, water filtration, erosion protection, and storm/flood protection. Provision of these services is dependent upon the resiliency of these vulnerable coastal environments to climate change, and changes in sea level and storm frequency/intensity. This report summarizes coastal vulnerability assessments based on peer-reviewed journal articles and published reports. Topics addressed include (1) an introduction to coastal vulnerability, (2) factors contributing to coastal vulnerability, (3) a review and synthesis of coastal vulnerability assessment methods, and (4) knowledge gaps and opportunities for additional research. The variables most commonly used for vulnerability assessments are reduced to 13 variables that apply across geologic, physical, and socioeconomic processes. Approaches for developing a coastal vulnerability assessment are reviewed, and an approach based on a calculation of the square root of the product mean of variable(s) of interest is the most commonly used assessment technique. Socioeconomic vulnerability is recognized as a critical component of vulnerability assessments that is often excluded because of inherent difficulties in data collection.

DISCLAIMER: The contents of this report are not to be used for advertising, publication, or promotional purposes. Citation of trade names does not constitute an official endorsement or approval of the use of such commercial products. All product names and trademarks cited are the property of their respective owners. The findings of this report are not to be construed as an official Department of the Army position unless so designated by other authorized documents. 


\section{Contents}

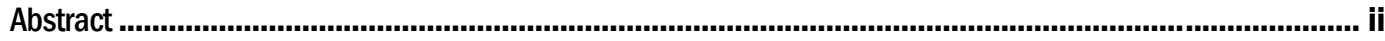

Figures and Tables...........................................................................................................................................

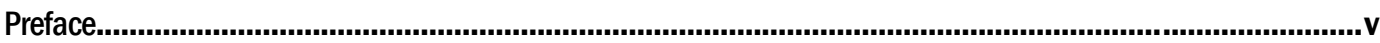

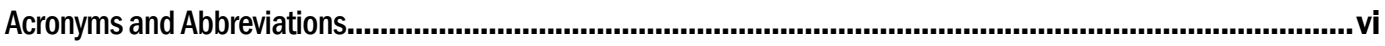

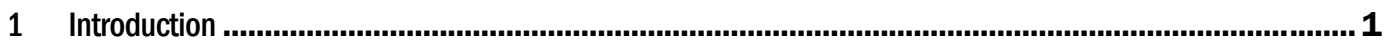

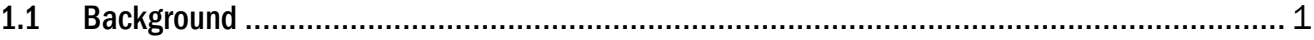

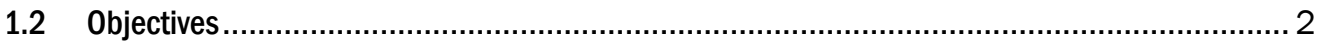

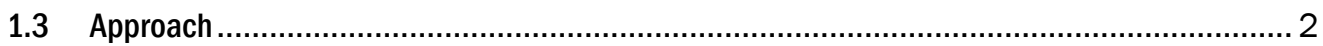

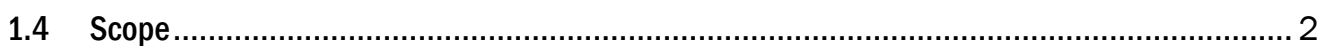

2 Coastal Vulnerability ................................................................................................................ 3

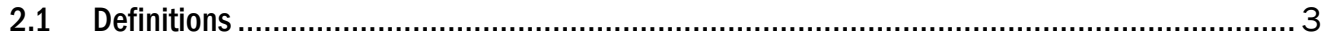

2.2 Contributing factors to coastal vulnerability ....................................................... 5

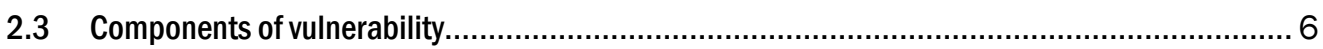

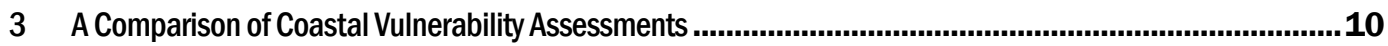

3.1 Coastal vulnerability calculations ........................................................................ 11

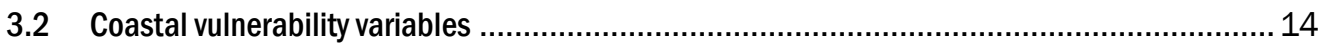

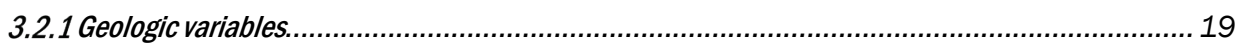



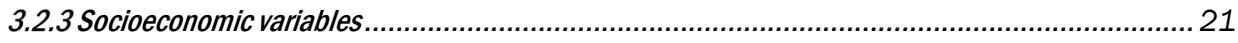

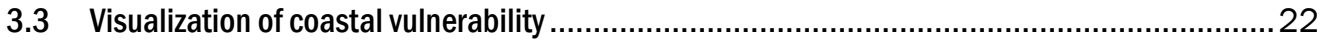

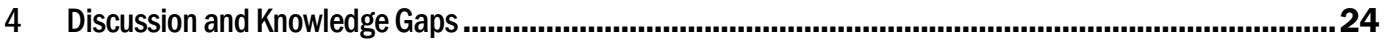

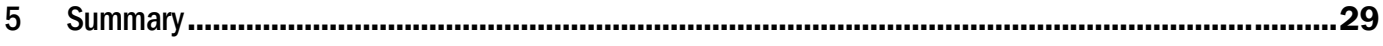

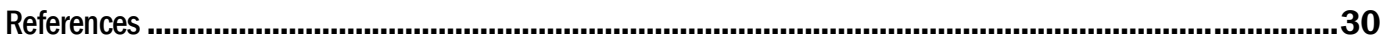

\section{Report Documentation Page}




\section{Figures and Tables}

\section{Figures}

Figure 1. The top identified geologic, physical, and socioeconomic variables used to calculate coastal vulnerability.

\section{Tables}

Table 1. The reference, purpose, location, and coastal vulnerability index (CVI) calculation used for each identified vulnerability assessment. $* R=$ weight factor; RSLR, relative sea level rise; $\mathrm{CCFVI}=$ Coastal city flood vulnerability index, where hydro-geologic, socio-economic, and politico-administrative indicators are categorized either as exposure, susceptibility, or resilience factors. 12

Table 2. Geologic variables considered in coastal vulnerability assessments................................. 15

Table 3. Physical variables considered in coastal vulnerability assessments.................................. 16

Table 4. Socioeconomic variables considered in coastal vulnerability assessments. 


\section{Preface}

This study was conducted for the Ecosystem Management and Restoration Research Program under Project Number 2016-ER-5 "Assessing and Improving the Resilience of Bay and Coastal Marshes and Islands." The program manager was Dr. Trudy J. Estes.

The work was performed by the U.S. Army Engineer Research and Development Center-Environmental Laboratory (ERDC-EL), Wetlands and Coastal Ecology Branch (EEW), Ms. Patricia M. Tolley, Chief, and the Environmental Engineering Branch (EPE), Dr. William A. Martin, Chief. At the time of publication, Mr. Mark D. Farr was Chief of the Ecosystem Evaluation and Engineering Division (EE) of ERDC-EL, Mr. Warren P. Lorentz was Chief of the Environmental Processes and Engineering Division (EP), and Dr. Alfred F. Cofrancesco was the Technical Director (EZT). The Deputy Director of ERDC-EL was Dr. Jack E. Davis, and the Director was Dr. Ilker R. Adiguzel.

COL Ivan P. Beckman was Commander of ERDC, and Dr. David W. Pittman was the Director. 


\section{Acronyms and Abbreviations}

\begin{tabular}{|l|l|}
\hline Acronym & \multicolumn{1}{|c|}{ Meaning } \\
\hline DIVA & Dynamic and Interactive Vulnerability Assessment \\
\hline DoD & Department of Defense \\
\hline EE & Ecosystem Evaluation and Engineering Division \\
\hline EP & Environmental Processes and Engineering Division \\
\hline EEW & Wetlands and Coastal Ecology \\
\hline EMRRP & Ecosystem Management and Restoration Research Program \\
\hline EL & Environmental Laboratory \\
\hline EPE & Environmental Engineering Branch \\
\hline ERDC & Engineer Research and Development Center \\
\hline GIS & Geographic Information System \\
\hline USACE & U.S. Army Corps of Engineers \\
\hline
\end{tabular}




\section{Introduction}

\subsection{Background}

Coastal areas frequently include an interface between dynamic environmental systems and concentrated populations and infrastructure (Romieu et al. 2010). Coastal areas are vulnerable to a number of factors including erosion, subsidence, and changes in hydrology, and are often in areas with increasing population densities (Ozyurt and Ergin 2010). With changing climate and sea level, many coastal systems will experience a number of potential environmental changes. These changes may include increased wetland inundation frequency and duration, accelerated coastal erosion, saltwater intrusion into fresh groundwater, encroachment of tidal waters into estuaries and rivers, or elevated sea-surface and ground temperature (IPCC 2001a; Thatcher et al. 2013). The potential for environmental and economic damage is exacerbated by coastal development, resulting in already degraded coastal habitats (i.e., marshes, beaches, and islands) being more vulnerable to losses (Doukakis 2005a; Klein et al. 1998).

Coastal habitats provide significant ecological services in addition to protection of coastal populations and infrastructure. Specifically, coastal areas provide services including, but not limited to, wildlife habitat, carbon sequestration, water filtration, erosion protection, and flood protection (Hauser et al. 2015). They also provide important nursery habitat to many commercially fished species (Boesch and Turner 1984) as well as their forage species. Resiliency of these vulnerable coastal environments is necessary to continue providing these services. Therefore, vulnerability assessments are key to evaluating the susceptibility of coastal habitats. These assessments provide means to quantify the vulnerability of different coastal habitats, and a method to compare restoration alternatives or potentials (Bridges et al. 2015) in order to improve coastal planning and management (Doukakis 2005b).

The U.S. Army Corps of Engineers (USACE) restores and protects aquatic resources under its aquatic ecosystem restoration and mission. In addition, the USACE is required to assess the impacts of proposed water resource projects to the environment (e.g., dredging of federal waterways) as part of environmental compliance and planning procedures. Coastal 
vulnerability assessments can be utilized to prioritize aquatic resources for restoration or protection. The first step in incorporating coastal vulnerability assessments into the USACE planning procedures is to evaluate the current state of the science for vulnerability assessments of coastal systems.

\subsection{Objectives}

This report was undertaken to examine lessons learned from coastal vulnerability assessments, highlight the challenges associated with defining coastal vulnerability, compare and evaluate vulnerability assessment methods, and identify knowledge gaps and research opportunities related to coastal vulnerability assessments.

\subsection{Approach}

This report addresses topics related to the assessment of coastal vulnerability to changes in sea level and storm frequency/intensity, and is based on a review of peer-reviewed journal articles and published reports. These coastal vulnerability assessments utilize a number of different components and variables of vulnerability, focusing primarily on coastal geophysical variables. In the majority of the published assessments, socioeconomic variables were either not considered, or were limited in the vulnerability assessments reviewed, despite the acknowledgement that including socioeconomic variables is necessary.

\subsection{Scope}

The following review focuses on synthesizing available coastal vulnerability assessments, including biogeophysical and socioeconomic assessments. Specific areas addressed within this report include: (1) an introduction to coastal vulnerability, (2) brief overview of contributing factors to coastal vulnerability, (3) a review and synthesis of coastal vulnerability assessments, (4) knowledge gaps and opportunities for additional research. 


\section{Coastal Vulnerability}

Impacts to coastal communities from sea level rise, increased storm intensity, and increased frequency of storms coupled with coastal development are forcing cities, regions, and nations to consider where and how to protect vulnerable coastal resources. As such, coastal vulnerability is often discussed, and assessments developed, to evaluate the risk of coastal regions due to physical, environmental, social, and economic vulnerabilities (Sahoo and Bhaskaran 2018). Events such as Superstorm Sandy demonstrate the need to assess coastal vulnerability in order to inform appropriate coastal zone management.

A number of previous studies demonstrate the complexity of defining vulnerability, the various approaches applied to assessing coastal vulnerability, and the challenges associated with gathering data for use in vulnerability assessments. This section presents definitions related to coastal vulnerability, describes three different elements of coastal vulnerability, and discusses factors, such as sea level rise and increased storm frequency/intensity that contributes to the vulnerability of coastal habitats.

\subsection{Definitions}

Vulnerability is a concept that incorporates physical, geologic, economic, institutional, and sociocultural components to associated impacts (Klein and Nicholls 1999). In addition, the concept of vulnerability integrates human value judgments concerning risk to various elements or sources of risk (Green and McFadden 2007; Klein et al. 1998). For example, infrastructure, quality of life, natural resources, cultural resource, and habitat are different elements of a system deemed valuable by humans or that perform functions valuable to humans (Green and McFadden 2007). The system is considered vulnerable if these values or functions are potentially impacted or threatened (Aven 2011).

Vulnerability is defined as a system's ability to cope with adverse effects of stress or hazards (Bridges et al. 2015). Specifically, coastal vulnerability is defined as the degree of incapability of a coastal system to cope with the consequences of climate change, climate extremes, and accelerated sea level rise (IPCC CZMS 1992; IPCC 2001b). Coastal vulnerability is a function of the physical and geologic nature of the coastal system, 
frequency and magnitude of perturbations, degree of change on human activities and properties, and the system's capacity to adapt (Adger 2006; Arkema et al. 2013; McLaughlin and Cooper 2010).

The degree of vulnerability is a function of the susceptibility, resilience, and resistance of a coastal system to cope with stress or hazards (Klein and Nicholls 1999). Susceptibility reflects the potential for a coastal system to be effected by a stressor and is an intrinsic property of the system (Adger 2006). For instance, a system with soft sediments is more susceptible to changes from storm surge than a system with hard sediments (Capobianco et al. 1999). Resilience and resistance are functions of the stability of a system to perturbations (Klein et al. 1998). Resilience defines the speed of recovery from a stressor (Aven 2011) and resistance defines the ability of a system to avoid perturbation (Klein and Nicholls 1999). Resistance of a coastal system is important prior to a perturbation; while resilience is important following a perturbation (Klein et al. 1998).

Vulnerable coastlines typically are characterized by low coastal elevation, erodible substrate (e.g., sand or other unconsolidated sediments), evidence of past or present subsidence, shoreline retreat, higher wave/tide energies, and high probability of storm activity (e.g., hurricane) (Daniels et al. 1992). Sea level rise and increasing storm frequency/intensity are contributing factors to the vulnerability of coastal systems (Hauser et al. 2015). The assessment of coastal vulnerability, including the systems susceptibility, resilience, and resistance, provides the opportunity to guide adaptive management strategies (Doukakis 2005b; McLaughlin et al. 2002).

Human activities often influence the resilience and resistance of a coastal system to perturbations, whereas, susceptibility is an inherent property of a particular system (Klein et al. 1998). Human activity changes the physical characteristics (i.e., infrastructure) of a coastline resulting in a decline in ecosystem resistance and loss of infrastructure protection that a coastal system would have provided from perturbations. Increased ecosystem stress resulting from human activity reduces the resilience of the coastal system (Klein et al. 1998). Therefore, the addition of increasing populations and infrastructure to coastal areas increases the vulnerability of coastal habitats, people, and infrastructure (Klein and Nicholls 1999). 


\subsection{Contributing factors to coastal vulnerability}

Coastal systems are the transition between upland and marine systems resulting in constant change, movement, accretion, and erosion because of natural processes associated with wind and water (Hedge and Reju 2007). In addition to these natural processes, sea levels are rising and storm intensities/frequencies are increasing (Hauser et al. 2015). These factors contribute to the vulnerability of coastal systems by increasing inundation duration, flood frequency, and erosion (Cahoon et al. 2006). Summarily, these changes result in stresses on coastal habitats and loss of ecological function (Barbier et al. 2008).

Relative sea level rise is a combination of eustatic (global) sea level rise and local changes in sea level (Nicholls and Casanave 2010). Relative sea level rise changes the local tidal datum elevation, which defines inundation frequency and duration levels for coastal systems. Consolidation (Nicholls 2003), subsurface groundwater or hydrocarbon withdrawal (Kolker et al. 2011), tectonic activity (Zervas 2009), and sediment supply (Kirwan et al. 2010) contribute to changes in the relative sea level. An increase in relative sea level can result in more frequent or longer durations of inundation and accelerated erosion. Excessive inundation reduces vegetation growth as root systems are forced to cope with anaerobic conditions (Mendelssohn and McKee 1988). Herbivore damage from estuarine grazers, such as purple marsh crabs (Sesarma reticulatum) also increases with increased inundation (Smith et al. 2012). Ultimately, stressors associated with excessive inundation can result in vegetation death (Stagg and Mendelssohn 2010) and loss of ecological functions associated with coastal systems (Day et al. 2011).

Erosion is a natural response to coastal water and wind processes. In coastal areas where erosion is a prominent coastal process, human development can be at risk, either by natural erosional processes, or modification to the littoral system (Hedge and Reju 2007). Often, anthropogenic alterations to the littoral system contribute to the vulnerability of coastal systems. Modifications to sediment sources, or sinks, may contribute to erosion, and thus, increase the vulnerability of coastal systems (Hedge and Reju 2007). Sediment supply to coastal areas has diminished nationwide because of anthropogenic activities including reforestation, urbanization, agricultural sediment-control, dam construction (Kirwan et al. 2010), and levee construction (Day et al. 2007). Interruptions in coastal sediment supply may reduce the capacity of 
coastal habitats (e.g., marshes, beaches, dunes) in some locations to aggrade both vertically and horizontally in response to subsidence and relative sea level rise (Kirwan et al. 2010; Mariotti and Fagherazzi 2013; Mudd 2011; Turner 1997). Wetlands have varying ability to compensate for sea level rise, with tidal regime and total suspended solids (TSS) concentration often determining the ability of wetlands to persist in the face of sea level rise. In cases where both the TSS is high (>30 mg/l), and the tidal range is high $(\sim 2 \mathrm{~m})$, wetlands often continue to persist at present rates of sea level rise and, to a significant degree, future projected rates of SLR (Kirwan et al. 2016).

Rising water levels, which also results in increased wave energy from higher water levels, degrade surface and edges of coastal systems through erosion (Heberger et al. 2009; Reed 2002). Erosion of the surfaces and edges of coastal areas can result in export of sediment and carbon from the system (Ganju et al. 2015). Edge and surface erosion is often mitigated by the presence of vegetation, particularly in marsh systems (Baustian et al. 2012). Vegetation increases roughness, thus, decreasing wind-wave resuspension of exposed sediments (Baustian et al. 2012), while the root system holds soil in place. Furthermore, storms are known to cause disturbance and degradation to coastal areas from high velocity winds and associated wave and storm surge (Hauser et al. 2015). Shoreline erosion, flooding, and property damage are examples of possible storm damage (Hauser et al. 2015).

Anthropogenic changes to these systems intensify the susceptibility of coastal areas to perturbations. These changes, in addition to sea level rise and increasing storm frequency/intensity, are also increasing the vulnerability of coastal systems. Sea level rise increases wave energy and inundation frequency and duration, causing both erosion and vegetation degradation. Storms result in shoreline erosion, flooding, and property damage. Together, these factors contribute to the increased risk in coastal erosion and inundation, and ultimately coastal vulnerability (Gornitz et al. 1997). Additional factors that contribute to coastal vulnerability, yet are frequently overlooked, are variations in precipitation patterns, and temperature (Burkett and Davison 2012).

\subsection{Components of vulnerability}

Coastal systems are highly vulnerable to changes in climate, including changes in sea level and storm frequency/intensity (Klein and Nicholls 
1999). As such, a number of efforts to assess coastal vulnerability have been developed. Different future outcomes are also considered depending on the collective response to climate change in coastal regions worldwide (Nicholls et al. 2008). Assessments are primarily focused on the vulnerability of coastal systems to sea level rise (Addo 2013; Gornitz and White 1992, 1994; Gornitz et al. 1994, 1997; Klein and Nicholls 1999; Theiler and Hammer-Klose 2000a; Ozyurt and Ergin 2010; Thatcher et al. 2013; Pendleton et al. 2010a; IPCC CZMS 1992) or erosion (McLaughlin and Cooper 2010; McLaughlin et al. 2002; Doukakis 2005a; Hedge and Reju 2007). Coastal vulnerability assessments also consider vulnerabilities related to tropical cyclones (Bahinipati 2014; Sahoo and Bhaskaran 2018) and coastal flooding (Balica et al. 2012; Bahinipati 2014).

A number of different aspects are considered in vulnerability assessments. These aspects range from the specific components of vulnerabilities assessed in addition to the variables selected within each component. There are the following three components of coastal vulnerability: physical, geologic, and socioeconomic. The physical, geologic, and socioeconomic vulnerabilities are clearly related and interdependent to each other, but can be distinguished from one another (Klein and Nicholls 1999).

The physical component of vulnerability assessments describe how a coastal system copes with perturbations to the physical processes that occur in coastal systems. Physical processes are naturally occurring in coastal systems and include variables such as wave height and tidal range (Hedge and Reju 2007; Pendleton et al. 2010). Physical processes occur over time scales of hours to centuries (Pendleton et al. 2010b). These physical processes account for coastal inundation, including changing sea level, and result in changes in the physical vulnerability of coastal systems (Pendleton et al. 2010a). The inclusion of physical processes into coastal vulnerability assessments can aid scientists and planners in evaluating the likelihood of increased inundation frequency and duration along coastlines as sea levels continue to rise (Pendleton et al. 2010b).

The geologic component of vulnerability takes into account geologic history and a coastal system's inherent erodibility due to geology. Variables considered in geologic vulnerability are the result of processes that occur over longer time scales than physical processes. Geologic vulnerability incorporates variables that include, but are not limited to, geomorphology, mean elevation, and historic shoreline change (Pendleton et al. 2010b). 
The geologic variables account for the relative resistance of a coastal system to erosion (Pendleton et al. 2010b). Inclusion of geologic variables into coastal vulnerability assessments can aid scientists and planners in evaluating the likelihood of erosion along coastlines as rising sea levels increase wave energy and storm frequencies/intensities increase (Pendleton et al. 2010a).

Socioeconomic vulnerability is determined by the impact potential and society's technical, institutional, economic, and cultural ability to prevent or cope with the coastal systems' physical and geologic vulnerabilities (Klein et al. 1998). The physical and geologic components of vulnerability related to rising sea levels and storm frequencies/intensities on coastal systems result in a range of socioeconomic impacts, thus, increasing socioeconomic vulnerabilities. Socioeconomic vulnerability incorporates (1) perceived social and economic worth of resources within a given area that is at risk, (2) the cost of infrastructure (i.e., buildings or roads) to the vulnerability assessment (McLaughlin et al. 2002), and (3) determines the effort to protect those resources (Gornitz et al. 1993). The inclusion of economic variables, such as type and density of residential and commercial buildings, highlight where major economic and infrastructural losses may be expected (Thatcher et al. 2013). The potential socioeconomic vulnerabilities are similar to the susceptibility of a natural system, and are a function of the resilience and resistance of the human system to prevent or cope with impacts (Klein et al. 1998).

There are many potential indicators of socioeconomic value, and therefore, socioeconomic vulnerability (Hedge and Reju 2007). However, many coastal vulnerability assessments focus on variables related to physical and geologic components of vulnerability, despite acknowledgement that socioeconomic vulnerability needs to be included (Gornitz et al. 1991; McLaughlin et al. 2002). The exclusion of socioeconomic variables can limit the evaluation of vulnerable coastal systems (Harvey et al. 1999). Several reasons for limited use of socioeconomic variables in vulnerability assessments have been reported. Omission of socioeconomic variables include lack of available usable data (Hedge and Reju 2007), inherent difficulty ranking socioeconomic data on an interval scale (McLaughlin et al. 2002), time constrained data (i.e., changing population numbers; Hedge and Reju 2007), and changing human perceptions (McLaughlin et al. 2002). 
Physical, geologic, and socioeconomic components each represent different aspects of the adaptive capacity of coastal systems to perturbations (Klein et al. 1998). Components of physical vulnerability assessments capture variables related to inundation, geologic vulnerability components capture variables related to erosion potential, and socioeconomic variables capture vulnerabilities to populations and infrastructure. As coastal systems are increasingly vulnerable because of large coastal populations, infrastructure, and climate changes, the importance of linking physical, geologic, and socioeconomic vulnerabilities is apparent (Klein and Nicholls 1999). 


\section{A Comparison of Coastal Vulnerability Assessments}

The main objectives of vulnerability assessments are to classify coastlines into units of similar characteristics (McLaughlin et al. 2002), determine the nature of vulnerability (e.g., erosion vs. inundation) (Ozyurt and Ergin 2010), and provide a relative ranking of potential coast line changes (Doukakis 2005b). These assessments are often expressed in quantitative terms, using an index of scale (1 to 5) (Romieu et al. 2010) to simplify complex and interacting variables that are used to inform management of coastlines (McLaughlin and Cooper 2010). Vulnerability assessments provide information to guide the process of adaptation and society's adaptive capacity (McLaughlin and Cooper 2010). Preventative management strategies can then be implemented in identified vulnerable areas using vulnerability assessments (Doukakis 2005b; McLaughlin et al. 2002).

Vulnerability assessments must consider what data is most appropriate to quantify the vulnerability in question and what data is available at the spatial scale of the study (McLaughlin and Cooper 2010; Romieu et al. 2010). The selection of data should reflect the outcome of change or the causal relationship that drives the change rather than the relative accessibility of data (Barnett et al. 2008). Assessments have been developed most often to study coastal vulnerabilities to sea level rise, wave erosion, or human impacts (Hedge and Reju 2007). Coastal vulnerability assessments were surveyed for the assessment purpose, location, calculation, and variables utilized in the calculation (Tables 1-4).

Seven assessments focused on the vulnerability of coastlines to erosion while 17 assessments focused on the vulnerability of coastlines to relative sea level rise. One assessment addressed both erosion and sea level rise vulnerability (Kumar and Kunte 2012), and one assessment compared two different coastal vulnerability calculations rather than focusing on specific coastal vulnerabilities (Paola et al. 2011). Three assessments focused on flood and/or extreme events (e.g., cyclones). Each variable was ranked from 1 to 5 , where one was least vulnerable and five was most vulnerable (Gornitz 1991), unless variables were first normalized (Balica et al. 2012; Bahinipati 2014; Sahoo and Bhaskaran 2018). The assignment of ranking values was 
different for each assessment and was dependent on the relative scale applied to the assessment (Bridges et al. 2015; Wamsley et al. 2015).

\subsection{Coastal vulnerability calculations}

Coastal vulnerability assessments were derived and calculated using several different formulas (Table 1), although largely based on formulas derived in Gornitz et al. (1991). The coastal vulnerability assessments were calculated using the product mean, square root of the product mean, or the sum of products. The product mean was used in two coastal vulnerability index calculations (Hedge and Reju 2007; Gornitz et al. 1991). The square root of the product mean was used most often, for a total of 19 times. The sum of products was used three times to calculate coastal vulnerability assessments. Two assessments calculated the coastal vulnerability index using two different calculations, the square root of the product mean and the sum of products (Diez et al. 2007; Rao et al. 2008).

In addition, new calculations for assessing coastal vulnerability have been developed, including the use of scaling or weighting variables, geometric means, and normalizing variables. Five coastal vulnerability assessments included a scaling or weight factor for each variable considered (Bahinipati 2014; McLaughlin and Cooper 2010; McLaughlin et al. 2002; Szlafztein and Sterr 2007; Ozyurt and Ergin 2010; Yin et al. 2012), while three assessments utilized the normalization technique (Balica et al. 2012; Bahinpati 2014; and Sahoo and Bhaskaran 2018). The geometric mean of all the ranked variables was used in an assessment developed by Arkema et al. (2013), and utilized in two freely available coastal vulnerability assessment visualization platforms. 
Table 1. The reference, purpose, location, and coastal vulnerability index (CVI) calculation used for each identified vulnerability assessment. * $\mathrm{R}=$ weight factor; RSLR, relative sea level rise; CCFVI = Coastal city flood vulnerability index, where hydro-geologic, socio-economic, and politico-administrative indicators are categorized either as exposure, susceptibility, or resilience factors.

\begin{tabular}{|c|c|c|c|}
\hline Reference & Driving Factor(s) & Study Location & CVI Calculation \\
\hline Sahoo and Bhaskaran 2018 & Cyclones & Odisha, India & Normalized; $\mathrm{CVI}=\left(\mathrm{X}_{1}+\mathrm{X}_{2}+\mathrm{X}_{3}+\ldots \mathrm{X}_{\mathrm{n}}\right) / \mathrm{n}$ \\
\hline Bahinipati 2014 & Cyclones/Floods & Odisha, India & Normalized; $\mathrm{CVI}=\left(\mathrm{X}_{1}+\mathrm{X}_{2}+\mathrm{X}_{3}+\ldots \mathrm{X}_{\mathrm{n}}\right) / \mathrm{n}$ \\
\hline Balica et al. 2012 & Floods & $\begin{array}{l}\text { Cities in Argentina, India, Morocco, } \\
\text { Bangladesh, Philippines, France, } \\
\text { Japan, China, and Netherlands }\end{array}$ & $\begin{array}{l}\text { Normalized; CCFVI = } \\
((\text { Exposure*Susceptibility)/Resilience) }\end{array}$ \\
\hline Addo 2013 & Erosion & Accra, Ghana & $C V I=\operatorname{sqrt}\left(\left(X_{1} * X_{2} * X_{3} * \ldots X_{n}\right) / n\right)$ \\
\hline Boruff et al. 2005 & Erosion & U.S. Coastal Counties & $C V I=\operatorname{sqrt}\left(\left(X_{1} * X_{2} * X_{3} * \ldots X_{n}\right) / n\right)$ \\
\hline Doukakis 2005b & Erosion & Peloponnese, Greece & $C V I=\operatorname{sqrt}\left(\left(X_{1} * X_{2} * X_{3} * \ldots X_{n}\right) / n\right)$ \\
\hline Hedge and Reju 2007 & Erosion & Mangalore, India & $C V I=\left(X_{1} * X_{2} * X_{3} * \ldots X_{n}\right) / n$ \\
\hline Kumar et al. 2010 & Erosion & Orissa State, India & $C V I=\operatorname{sqrt}\left(\left(X_{1} * X_{2} * X_{3} * \ldots X_{n}\right) / n\right)$ \\
\hline $\begin{array}{l}\text { McLaughlin \& Cooper 2010, } \\
\text { McLaughlin et al. } 2002 \text { * }\end{array}$ & Erosion & Northern Ireland & $C V I=\left(X_{1}+X_{2}+X_{3}\right) / 3$ \\
\hline Szlafztein and Sterr 2007* & Erosion & Para, Brazil & $\begin{array}{l}\mathrm{CVI}=\left(\left(1 X_{1}+0.5 X_{2}+0.25 X_{3}+X_{n}\right) / n\right)+ \\
\left.\left(1 Y_{1}+0.5 Y_{2}+0.25 Y_{3}+Y_{n}\right) / n\right) / 2\end{array}$ \\
\hline Kumar and Kunte 2012 & Erosion/RSLR & Tamil Nadu State, India & $C V I=\operatorname{sqrt}\left(\left(X_{1} * X_{2} * X_{3} * \ldots X_{n}\right) / n\right)$ \\
\hline Arkema et al. 2013 & RSLR & U.S. Coastlines & $C V I=\left(X_{1} * X_{2} * X_{3} * \ldots X_{n}\right)^{1 / n}$ \\
\hline Diez et al. 2007 & RSLR & Buenos Aires, Argentina & $\begin{array}{l}C V I=\operatorname{sqrt}((X 1 * X 2 * X 3 * \ldots X n) / n) \\
C V I=4 X_{1}+4 X_{2}+2\left(X_{3}+X_{4}\right)+4 X_{5}+2\left(X_{6}+X_{7}\right)\end{array}$ \\
\hline Gaki-Papanastassiou et al. 2010 & RSLR & Peloponnese, Greece & $C V I=\operatorname{sqrt}\left(\left(X_{1} * X_{2} * X_{3} * \ldots X_{n}\right) / n\right)$ \\
\hline $\begin{array}{l}\text { Gornitz 1990, 1991, } \\
\text { Gornitz and White 1992, } \\
\text { Gornitz et al. 1991, } 1997\end{array}$ & RSLR & Southeast U.S. & $\begin{array}{l}\mathrm{CVI}=\left(X_{1} * X 2 * X_{3} * \ldots X n\right) / n \\
C V I=\operatorname{sqrt}((X 1 * X 2 * X 3 * \ldots X n) / n) \\
C V I=4 X_{1}+4 X_{2}+2\left(X_{3}+X_{4}\right)+4 X_{5}+2\left(X_{6}+X_{7}\right)\end{array}$ \\
\hline Ozyurt and Ergin 2010* & RSLR & Goksu Delta, Turkey & $C V I=0.5 \operatorname{sum} X * R+0.5 \operatorname{sum} Y * R$ \\
\hline Pendleton et al. 2010 & RSLR & $\begin{array}{l}\text { National Parks along U.S. Atlantic, } \\
\text { Pacific, Gulf of Mexico, Gulf of Alaska, } \\
\text { Caribbean, Greak Lakes Coasts }\end{array}$ & $C V I=\operatorname{sqrt}\left(\left(X_{1} * X_{2} * X_{3} * \ldots X_{n}\right) / n\right)$ \\
\hline
\end{tabular}




\begin{tabular}{|c|c|c|c|}
\hline Reference & Driving Factor(s) & Study Location & CVI Calculation \\
\hline Rani et al. 2015 & RSLR & India Coastline & $\mathrm{CVI}=\operatorname{sqrt}\left(\left(\mathrm{X}_{1} * \mathrm{X}_{2} * \mathrm{X}_{3} * \ldots \mathrm{X}_{\mathrm{n}}\right) / \mathrm{n}\right)$ \\
\hline Rao et al. 2008 & RSLR & Andhra Pradesh Coast, India & $\begin{array}{l}\mathrm{CVI}=\operatorname{sqrt}\left(\left(\mathrm{X}_{1} * \mathrm{X}_{2} * \mathrm{X}_{3} * \ldots X_{n}\right) / \mathrm{n}\right) \\
\mathrm{CVI}=4 \mathrm{X}_{1}+4 \mathrm{X}_{2}+2 \mathrm{X}_{3}+\mathrm{X}_{4}+X_{5}\end{array}$ \\
\hline Thatcher et al. 2013 & RSLR & Northern US Gulf Coast & $\mathrm{CVI}=\operatorname{sqrt}\left(\left(\mathrm{X}_{1} * \mathrm{X}_{2} * \mathrm{X}_{3} * \ldots \mathrm{X}_{\mathrm{n}}\right) / \mathrm{n}\right)$ \\
\hline $\begin{array}{l}\text { Theiler and Hammar-Klose 1999, } \\
\text { Theiler and Hammar-Klose 2000a,b }\end{array}$ & RSLR & U.S. Atlantic, Gulf, and Pacific Coasts & $C V I=\operatorname{sqrt}\left(\left(X_{1} * X_{2} * X_{3} * \ldots X_{n}\right) / n\right)$ \\
\hline Yin et al. $2012^{*}$ & RSLR & Chinese coast & $C V I=\left(X_{1} * R_{1}\right)+\left(X_{2} * R_{2}\right)+\ldots\left(X_{n} * R_{n}\right)$ \\
\hline Paola et al. 2011 & $\mathrm{~N} / \mathrm{A}$ & San Agustin Canary Islands & $\mathrm{CVI}=\operatorname{sqrt}\left(\left(\mathrm{X}_{1} * \mathrm{X}_{2} * \mathrm{X}_{3} * \ldots \mathrm{X}_{\mathrm{n}}\right) / \mathrm{n}\right)$ \\
\hline
\end{tabular}




\subsection{Coastal vulnerability variables}

Variables utilized to calculate coastal vulnerability assessments were classified into three vulnerability components. These components are geologic vulnerability (coastal characteristics), physical vulnerability (coastal forcings), and socioeconomic vulnerabilities (McLaughlin and Cooper 2010; Pendleton et al. 2010b). In some cases, geologic and physical variables were not distinctly categorized as geologic or physical. If this was the case, variables were categorized following definitions in McLaughlin and Cooper (2010) and Pendleton et al. (2010a). Thirteen coastal vulnerability assessments incorporated variables from all three types of vulnerabilities and 18 coastal vulnerability assessments incorporated two types of vulnerabilities. In all but one case, geologic and physical vulnerability variables were included if two vulnerabilities were assessed.

There were 17 different geologic variables considered in the surveyed coastal vulnerability assessments (Table 2). The top five geologic variables were the following: shoreline change, geomorphology, coastal slope, elevation, and geology. There were also 19 different physical variables used in calculating coastal vulnerability indexes (Table 3). The top four physical variables were the following: mean tidal range, relative sea level rise, mean wave height, and significant wave height. There were 20 different socioeconomic variables considered in the surveyed coastal vulnerability assessments (Table 4). The top four socioeconomic variables are the following: population, land-use, infrastructure, and road/railway networks. The variables most often used in calculating coastal vulnerability are briefly described in more detail in Figure 1. 
Table 2. Geologic variables considered in coastal vulnerability assessments.

\begin{tabular}{|c|c|}
\hline Geologic Variables & References \\
\hline $\begin{array}{l}\text { Shoreline change } \\
\text { (Erosion/accretion) }\end{array}$ & $\begin{array}{l}\text { Addo } 2013 \text {, Boruff et al. 2005, Diez et al. 2007, Gornitz and White 1992, Gornitz 1990, 1991, Gornitz et al. } \\
\text { 1991, Gornitz et al. 1997, Klein and Nicholls 1999, Kumar and Kunte 2012, Kumar et al. 2010, McLaughlin } \\
\& \text { Cooper 2010, McLaughlin et al. 2002, Paola et al. 2011, Pendleton et al. 2010, Rani et al. 2015, Rao et al. } \\
\text { 2008, Sahoo and Bhaskaran 2018, Theiler and Hammar-Klose 1999, 2000, 2000, Yin et al. 2012, Hedge } \\
\text { and Reju } 2007 \text {, Thatcher et al. } 2013\end{array}$ \\
\hline $\begin{array}{l}\text { Geomorphology } \\
\text { (Coastal landform) }\end{array}$ & $\begin{array}{l}\text { Addo 2013, Arkema et al. 2013, Boruff et al. 2005, Diez et al. 2007, Doukakis 2005, Gornitz and White } \\
\text { 1992, Gornitz 1990, 1991, Gornitz et al. 1991, Gornitz et al. 1997, Kumar and Kunte 2012, Kumar et al. } \\
\text { 2010, Ozyurt and Ergin 2010, Paola et al. 2011, Pendleton et al. 2010, Rani et al. 2015, Rao et al. 2008, } \\
\text { Sahoo and Bhaskaran 2018, Theiler and Hammar-Klose 1999, 2000, 2000, Yin et al. 2012, Hedge and Reju } \\
\text { 2007, Thatcher et al. } 2013\end{array}$ \\
\hline Coastal slope & $\begin{array}{l}\text { Balica et al. 2012, Boruff et al. 2005, Doukakis 2005, Kumar et al. 2010, Ozyurt and Ergin 2010, Pendleton } \\
\text { et al. 2010, Rani et al. 2015, Rao et al. 2008, Sahoo and Bhaskaran 2018, Theiler and Hammar-Klose 1999, } \\
\text { 2000, 2000, Yin et al. 2012, Hedge and Reju 2007, Thatcher et al. } 2013\end{array}$ \\
\hline Elevation & $\begin{array}{l}\text { Addo 2013, Arkema et al. 2013, Diez et al. 2007, Gornitz and White 1992, Gornitz 1990, 1991, Gornitz et al. } \\
\text { 1991, Gornitz et al. 1997, Kumar and Kunte 2012, Kumar et al. 2010, McLaughlin \& Cooper 2010, } \\
\text { McLaughlin et al. 2002, Paola et al. 2011, Yin et al. } 2012\end{array}$ \\
\hline Geology (solid or drift) & $\begin{array}{l}\text { Addo 2013, Diez et al. 2007, Gornitz and White 1992, Gornitz 1990, 1991, Gornitz et al. 1991, Gornitz et al. } \\
\text { 1997, McLaughlin \& Cooper 2010, McLaughlin et al. 2002, Paola et al. } 2011\end{array}$ \\
\hline River discharge & Balica et al. 2012, McLaughlin \& Cooper 2010, McLaughlin et al. 2002, Szlafztein and Sterr 2007 \\
\hline Orientation & McLaughlin \& Cooper 2010, McLaughlin et al. 2002 \\
\hline Inland buffer & McLaughlin \& Cooper 2010, McLaughlin et al. 2002 \\
\hline Subsidence & Addo 2013, Balica et al. 2012, Doukakis 2005 \\
\hline Coastline length & Balica et al. 2012, Bhaninipati 2014, Szlafztein and Sterr 2007 \\
\hline Displacement & Doukakis 2005 \\
\hline Bathymetry & Kumar and Kunte 2012 \\
\hline
\end{tabular}




\begin{tabular}{|l|l|}
\hline \multicolumn{1}{|c|}{ Geologic Variables } & \\
\hline Sediment budget & Ozyurt and Ergin 2010 \\
\hline Proximity to coast & Ozyurt and Ergin 2010 \\
\hline Type of aquifer & Ozyurt and Ergin 2010 \\
\hline Coastline features & Szlafztein and Sterr 2007 \\
\hline Coastline complexity & Szlafztein and Sterr 2007 \\
\hline
\end{tabular}

Table 3. Physical variables considered in coastal vulnerability assessments.

\begin{tabular}{|l|l|}
\hline \multicolumn{1}{|c|}{ Physical Variables } & \multicolumn{1}{c|}{ References } \\
\hline Mean tidal range & $\begin{array}{l}\text { Addo 2013, Boruff et al. 2005, Diez et al. 2007, Doukakis 2005, Gaki-Papanastassiou et al. 2010, Kumar } \\
\text { and Kunte 2012, Kumar et al. 2010, Paola et al. 2011, Rao et al. 2008, Yin et al. 2012, Gornitz and White } \\
\text { 1992, Gornitz 1990, 1991, Gornitz et al. 1991, Gornitz et al. 1997, McLaughlin \& Cooper 2010, McLaughlin } \\
\text { et al. 2002, Ozyurt and Ergin 2010, Pendleton et al. 2010, Sahoo and Bhaskaran 2018, Thatcher et al. } \\
\text { 2013, Theiler and Hammar-Klose 1999, 2000, 2000 }\end{array}$ \\
\hline RSLR & $\begin{array}{l}\text { Arkema et al. 2013, Balica et al. 2012, Boruff et al. 2005, Gaki-Papanastassiou et al. 2010, Kumar and } \\
\text { Kunte 2012, Kumar et al. 2010, Rani et al. 2015, Yin et al. 2012, Gornitz and White 1992, Gornitz 1990, } \\
\text { 1991, Gornitz et al. 1991, Gornitz et al. 1997, Ozyurt and Ergin 2010, Pendleton et al. 2010, Sahoo and } \\
\text { Bhaskaran 2018, Thatcher et al. 2013, Theiler and Hammar-Klose 1999, 2000, 2000 }\end{array}$ \\
\hline Mean wave height & $\begin{array}{l}\text { Boruff et al. 2005, Diez et al. 2007, Doukakis 2005, Gaki-Papanastassiou et al. 2010, Paola et al. 2011, Yin } \\
\text { et al. 2012, Gornitz and White 1992, Gornitz 1990, 1991, Gornitz et al. 1991, Gornitz et al. 1997, Pendleton } \\
\text { et al. 2010, Thatcher et al. 2013, Theiler and Hammar-Klose 1999, 2000, 2000 }\end{array}$ \\
\hline Significant wave height & $\begin{array}{l}\text { Addo 2013, Kumar and Kunte 2012, Kumar et al. 2010, Rao et al. 2008, McLaughlin \& Cooper 2010, } \\
\text { McLaughlin et al. 2002, Ozyurt and Ergin 2010, Sahoo and Bhaskaran 2018, }\end{array}$ \\
\hline Extreme events & $\begin{array}{l}\text { Balica et al. 2012, Bahinipati 2014, Kumar et al. 2010, Rani et al. 2015, McLaughlin \& Cooper 2010, } \\
\text { McLaughlin et al. 2002, Sahoo and Bhaskaran 2018, }\end{array}$ \\
\hline Storm surge & $\begin{array}{l}\text { Arkema et al. 2013, Balica et al. 2012, Kumar and Kunte 2012, McLaughlin \& Cooper 2010, McLaughlin et } \\
\text { al. 2002, Sahoo and Bhaskaran 2018, }\end{array}$ \\
\hline
\end{tabular}




\begin{tabular}{|l|l|}
\hline \multicolumn{1}{|c|}{ Physical Variables } & \\
\hline Saltwater intrusion & Rani et al. 2015, Klein and Nicholls 1999 \\
\hline Coastal inundation & Rani et al. 2015, Klein and Nicholls 1999, Sahoo and Bhaskaran 2018, \\
\hline Wind exposure & Arkema et al. 2013 \\
\hline Surface waves & Rani et al. 2015 \\
\hline Tides and currents & Rani et al. 2015 \\
\hline Protection & Szlafztein and Sterr 2007 \\
\hline Flooding areas & Szlafztein and Sterr 2007 \\
\hline Rising water table & Klein and Nicholls 1999 \\
\hline Flood frequency & Klein and Nicholls 1999 \\
\hline Depth to groundwater & Ozyurt and Ergin 2010 \\
\hline Downstream water depth & Ozyurt and Ergin 2010 \\
\hline Ice cover & Pendleton et al. 2010 \\
\hline Rainfall & Sahoo and Bhaskaran 2018 \\
\hline
\end{tabular}

Table 4. Socioeconomic variables considered in coastal vulnerability assessments.

\begin{tabular}{|l|l|}
\hline \multicolumn{1}{|c|}{$\begin{array}{c}\text { Socioeconomic } \\
\text { Variables }\end{array}$} & \multicolumn{1}{c|}{ References } \\
\hline Population & $\begin{array}{l}\text { Arkema et al. 2013, Balica et al. 2012, Bahinipati 2014, Boruff et al. 2005, Hedge and Reju 2007, } \\
\text { McLaughlin \& Cooper 2010, McLaughlin et al. 2002, Thatcher et al. 2013, Sahoo and Bhaskaran 2018, } \\
\text { Szlafztein and Sterr 2007 }\end{array}$ \\
\hline Landuse & $\begin{array}{l}\text { Arkema et al. 2013, Bahinipati 2014, McLaughlin \& Cooper 2010, McLaughlin et al. 2002, Rani et al. 2015, } \\
\text { Sahoo and Bhaskaran 2018, Thatcher et al. 2013, Yin et al. 2012, Ozyurt and Ergin 2010 }\end{array}$ \\
\hline Infrastructure & Bahinipati 2014, Boruff et al. 2005Doukakis 2005, Sahoo and Bhaskaran 2018, Thatcher et al. 2013, \\
\hline Road/railway networks & Hedge and Reju 2007, McLaughlin \& Cooper 2010, McLaughlin et al. 2002, Sahoo and Bhaskaran 2018, \\
\hline
\end{tabular}




\begin{tabular}{|l|l|}
\hline \multicolumn{1}{|c|}{$\begin{array}{c}\text { Socioeconomic } \\
\text { Variables }\end{array}$} & References \\
\hline Poverty & Bahinipati 2014, Boruff et al. 2005, Szlafztein and Sterr 2007 \\
\hline Cultural heritage & Balica et al. 2012, McLaughlin \& Cooper 2010, McLaughlin et al. 2002 \\
\hline Conservation status & McLaughlin \& Cooper 2010, McLaughlin et al. 2002 \\
\hline Wealth & Boruff et al. 2005, Szlafztein and Sterr 2007 \\
\hline Demographics & Balica et al. 2012, Bahinipati 2014, Boruff et al. 2005, Szlafztein and Sterr 2007 \\
\hline $\begin{array}{l}\text { Awareness and } \\
\text { preparedness }\end{array}$ & Balica et al. 2012, Sahoo and Bhaskaran 2018 \\
\hline Property value & Arkema et al. 2013 \\
\hline Shelters & Balica et al. 2012 \\
\hline Literacy & Bahinipati 2014 \\
\hline Flood risk & Doukakis 2005 \\
\hline Water management & Balica et al. 2012, Bahinipati 2014, Doukakis 2005 \\
\hline $\begin{array}{l}\text { Reduced sediment } \\
\text { supply }\end{array}$ & Ozyurt and Ergin 2010 \\
\hline River flow regulation & Ozyurt and Ergin 2010 \\
\hline Engineered frontage & Ozyurt and Ergin 2010 \\
\hline $\begin{array}{l}\text { Groundwater } \\
\text { consumption }\end{array}$ & Ozyurt and Ergin 2010 \\
\hline $\begin{array}{l}\text { Natural protection } \\
\text { degradation }\end{array}$ & Ozyurt and Ergin 2010 \\
\hline
\end{tabular}


Figure 1. The top identified geologic, physical, and socioeconomic variables used to calculate coastal vulnerability.

\begin{tabular}{|c|c|c|}
\hline & Coastal Vulnerability & \\
\hline $\begin{array}{l}\text { Geologic Vulnerability } \\
\text { (Erosion) }\end{array}$ & $\begin{array}{l}\text { Physical Vulnerability } \\
\text { (Inundation) }\end{array}$ & $\begin{array}{l}\text { Socioeconomic Vulnerability } \\
\text { (Society) }\end{array}$ \\
\hline $\begin{array}{l}\text { - Shoreline change } \\
\text { - Geomorphology } \\
\text { - Coastal slope } \\
\text { - Elevation } \\
\text { - Geology }\end{array}$ & $\begin{array}{ll}\text { - } & \text { Mean tidal range } \\
\text { - } & \text { Relative sea level rise } \\
\text { - } & \text { Significant wave height }\end{array}$ & $\begin{array}{l}\text { - } \text { Population } \\
\text { - } \text { Landuse } \\
\text { - Infrastructure } \\
\text { - } \text { Road/railway networks }\end{array}$ \\
\hline \multicolumn{3}{|c|}{ Ranking of potential changing coastlines } \\
\hline
\end{tabular}

\subsubsection{Geologic variables}

Shoreline change: Coastal shorelines are naturally subjected to change due to a number of coastal processes, including wave characteristics, nearshore circulation, sediment characteristics, or beach form (Kumar et al. 2010). This variable relates shoreline change to the rate of erosion or accretion to coastal vulnerability. Coastlines subjected to erosion are considered more vulnerable because of loss of private or public land, infrastructure, and coastal habitats (e.g., beaches, dunes, and wetlands) (Kumar et al. 2010). Erosion processes also reduce the distance between coastal populations and the ocean, thus, increasing the exposure of coastal populations to coastal vulnerabilities (Kumar et al. 2010). Coastlines subjected to accretionary processes are less vulnerable as additional land is created (e.g., accreting deltas) (Rao et al. 2008).

Geomorphology: Geomorphology is the study of landforms and geologic processes that lead to these landforms, and identifies similarities among landforms (Kumar et al. 2010). Of particular importance to coastal vulnerability is that geomorphology defines the erodibility of different landform types (Pendleton et al. 2010a). Erosion, and rising sea levels, will re-distribute coastal landforms such as intertidal flats, marshes, dunes, etc. because of increased wave erosion and storm surges (Kumar et al. 2010). The evolution of coastal geomorphic features will change coastal habitat and population/infrastructure vulnerabilities. Coastal areas with rocky shorelines, for example, are highly resistant to erosion and are therefore, less vulnerable (Rao et al. 2008). Coastal areas with sandy or muddy landforms (e.g., dunes, wetlands, mudflats) are the least resistant, 
and are therefore, extremely vulnerable to the effects of erosion and sea level rise (Kumar et al. 2010, Rao et al. 2008).

Coastal slope: Slope describes the measurement of steepness or gradient of the coast (Kumar et al. 2010). The slope of the coast indicates the potential for inundation by flooding (Ku-mar et al. 2010) and rapid shoreline retreat (Pendleton et al. 2010a). Coastal slope is an important variable to consider in vulnerability assessments because the slope is related to the risk of flooding due to relative sea level rise and storm surges (Kumar et al. 2010). Coastlines with lower, gentle, slopes have the potential for greater flooding and land loss; coastlines with higher, steeper, slopes are areas of low vulnerability (Kumar et al. 2010; Rao et al. 2008).

Elevation: Elevation is the average elevation above mean sea level of a particular coastal area. Coastal elevation is important to include in vulnerability assessments because elevation can be utilized to (1) identify and estimate extent of land threated by inundation from sea level rise, (2) estimate potential available land for wetland migration, and (3) identify sea level rise impacts to human populations and infrastructure (Kumar et al. 2010). Coastal areas with higher elevations are considered less vulnerable, because higher elevations are more resistant to inundation from sea level rise or storm surge (Kumar et al. 2010). Lower elevation coastlines are, therefore, highly vulnerable to inundation and erosion.

Geology: Geology (lithology) identifies the rock type of the coastal system (Gornitz et al. 1997). The geology is related to the resistance of the coastal substrate to erosion using the relative hardness of minerals comprising the rock type (Diez et al. 2007; Gornitz et al. 1997). The geology of coastal systems are classified as resistant rocks, sedimentary rocks, unconsolidated sediments, recent volcanic materials, and coral reefs (Gornitz et al. 1997). Those coastal areas with resistant geologic rocks are least vulnerable to erosive effect of sea level rise and storm surges; coastal areas with unconsolidated sediments are highly vulnerable to erosion due to sea level rise and storm surges.

\subsubsection{Physical variables}

Mean tidal range: Tides are a function of the gravitational pull of the moon and sun, and are highly predictable. The tidal range of a coastal area is the vertical distance between the highest high tide and the lowest low tide (Kumar et al. 2010; Yin et al. 2012). The tendency in coastal 
vulnerability assessments is to designate coastlines with high tide ranges as highly vulnerable (Kumar et al. 2010; Gornitz et al. 1997).

Relative sea level rise: Relative sea level rise is a combination of eustatic (global), regional, and local changes in sea level (Nicholls and Casanave 2010; Yin et al. 2012). Coastlines subjected to high relative sea level rise rates are considered highly vulnerable areas due to the potential inundation of coastal land (Kumar et al. 2010). Coastlines with low relative sea level rise rates are less vulnerable to inundation, and are therefore, less vulnerable to the effects of relative sea level rise. Sea level rise impacts shoreline change, geomorphology, land use, land cover, and groundwater resources (Rani et al. 2015). Sea level rise increases inundation of coastal areas and increases the rise of flooding by storm surges (Rani et al. 2015).

Mean wave height: Waves, along with long shore currents, actively transform coastal areas by shoreline transport of sediment (Doukakis 2005b). Mean wave height is a proxy for wave energy, which is the dominate force related to coastal sediment movement and erosion/depositional events (Yin et al. 2012). Wave height can be an indicator of the amount of sediment that is susceptible to offshore movement and removal from the coastal sediment system (Doukakis 2005b). The mobility and transport of coastal sediments by waves is a function of the wave height squared (Yin et al. 2012).

Significant wave height: Significant wave height is similar to mean wave height. However, significant wave height is the average height (trough to crest) of the one-third highest waves within a 12-hour period (Kumar et al. 2010). The height of waves is dependent on the wind generating the waves. Significant wave height is used as a proxy for wave energy, which is an important component to coastal sediment transport (Kumar et al. 2010; Kumar and Kunte 2012). As wave energy increases, the mobilization and transport of coastal material also increases. Coastal areas with higher significant wave height are considered more vulnerable than coastal areas with lower significant wave heights (Kumar et al. 2010).

\subsubsection{Socioeconomic variables}

Population: Coastal population is an estimate of the number of people that live near the coastline. The population variable is sometimes viewed as an economic variable as well, as people are invested in protecting their property from erosion and inundation (Hedge and Reju 2007; McLaughlin 
et al. 2002). Additionally, populations may cause increased erosion along the coastline (Hedge and Reju 2007). A coast with a larger population will incur a higher economic cost to protect houses, land, possessions, and infrastructure. On the other hand, a coastal area where few people live is less vulnerable to environmental degradation and has less infrastructure to protect (McLaughlin et al. 2002).

Land use: Land use can be defined in a number of ways, from economic, cultural, or environmental (McLaughlin et al. 2002). In most cases, land use is grouped and ranked according to monetary value to humans (McLaughlin et al. 2002; Yin et al. 2012). Land use types that are more valuable to humans are ranked as more vulnerable than land uses less valuable to humans (McLaughlin et al. 2002). For instance, urban and industrial infrastructure and agricultural areas are ranked as highly vulnerable; coastal habitats are ranked as less vulnerable (McLaughlin et al. 2002; Rani et al. 2015; Yin et al. 2012). These land use ranking system does not take into account benefits and services provided by coastal habitats or the potential future land use value (McLaughlin et al. 2002).

Infrastructure: Infrastructure is a broad category that includes the economic value of residential and commercial buildings (Thatcher et al. 2013). Additional infrastructure included in economic evaluations include schools, hospitals, wastewater treatment plants, potable water facilities, electric power plants, and other industry infrastructure (Thatcher et al. 2013). Coastal areas with more infrastructure are much more vulnerable than coastal areas with less infrastructure.

Road/railway networks: Road and railway networks are incorporated into coastal vulnerability assessments because roads and railway lines occupy defined lengths and widths (McLaughlin et al. 2002). In addition, the cost to protect, replace, or relocate are relatively easy to evaluate (McLaughlin et al. 2002). Coastal areas with numerous roads and railways, such as highways or interstates, are highly vulnerable while coastal areas with no or few roads and railways are much less vulnerable (McLaughlin and Cooper 2010).

\subsection{Visualization of coastal vulnerability}

Coastal vulnerabilities were visually represented utilizing geographic information system (GIS) in several assessments. For example, Kumar et al. (2010) use of the square root of the product mean to calculate coastal 
vulnerability in combination with GIS techniques. Sahoo and Bhaskaran (2018) combined the use of the square root of the product mean of variable(s) of interest (Gornitz et al. 1997) to calculate physical vulnerability and the normalized technique used in Bahinipati (2014) to calculate social and environmental vulnerabilities. The three vulnerabilities were aggregated and visually represented in ArcGIS (Sahoo and Bhaskaran 2018). Addo (2013) utilized GIS to map vulnerable coastal areas in Ghana.

In addition, several freely available tools also incorporate coastal vulnerability assessments into visualization platforms. The Coastal Resilience risk explorer tool (http://coastalresilience.org) utilizes the geometric mean of ranked biogeophysical variables (Gornitz et al. 1993; Theiler and Hammar-Klose 1999) to assess exposure in conjunction with social vulnerability (Arkema et al. 2013). Whereas, the InVEST coastal vulnerability modeling tool (www.naturalcapitalproject.org) uses the geometric mean of ranked biogeophysical variables, same as the Coastal Resilience tool, but also considered erosion and habitat exposure in the tool (Arkema et al. 2013). Hinkle and Klein (2009) developed the Dynamic and Interactive Vulnerability Assessment (DIVA) tool that models coastal vulnerabilities across different scales and integrated a graphical user interface. These platforms, for example, offer advantages of combining multiple vulnerability effects and visualization yet the underlying calculations and variables utilized in these coastal vulnerability assessments are much the same as described above (Arkema et al. 2013; Sahoo and Bhaskaran 2018). 


\section{Discussion and Knowledge Gaps}

The coastal vulnerability assessments reviewed are different from each other, with different components of vulnerability considered, a diversity of variables selected, and different types of calculations utilized. Coastal vulnerability assessments depend on many factors, notably the scale and purpose of the assessment (Cooper and McLaughlin 1998; Wamsley et al. 2015), and is reflected in the diversity of coastal vulnerability assessments reviewed.

The scale of coastal vulnerability assessments ranged from national (Yin et al. 2012; Gornitz et al. 1991), regional (Gornitz et al. 1994; Thieler and Hammar-Klose 1999), and local (Doukakis 2005a; Paolo et al. 2011). The purpose for developing coastal vulnerability assessments was most often related to erosion or sea level rise, although tropical cyclones and coastal flooding were considered. The selection of variables to calculate coastal vulnerability assessments frequently reflected the purpose of the assessment. Geologic and physical processes variables were most often identified in coastal vulnerability assessments. Consideration of socioeconomic variables is increasing in frequency and these variable are being incorporated more often into coastal vulnerability assessments.

Assessments consider a wide range of variables (Cooper and McLaughlin 1998). Williams et al. (1993) developed a dune vulnerability assessment that incorporated 54 different variables. While Cutter et al. (2003) used a principle component analysis (PCA) to reduce 42 variables to 11 variables in a social vulnerability assessments, and Pendleton et al. (2010) utilized PCA to identify the relative importance of variables within coastal vulnerability calculations. A previous survey of coastal vulnerability assessments noted that the number of variables ranged from 6-19 (Cooper and McLaughlin 1998). The coastal vulnerability assessments reviewed in this document frequently considered 6-10 variables (Tables 2-4). Wamsley et al. (2015) suggested coastal vulnerability be assessed with as few variables as necessary to measure the relevant vulnerability; many assessments reviewed in this document follow this suggestion.

Shoreline change (erosion/accretion), geomorphology, coastal slope, elevation, and geology were the geologic variables most often considered in coastal vulnerability assessments. These variables reflect coastal processes that influence the erodibility of coastal areas. In some cases, 
geology and geomorphology were included as one variable because geomorphology often includes both the landform and the landform rock type (Yin et al. 2012). Relative sea level rise, mean tidal range, mean wave height, and significant wave height were the physical variables most often considered in coastal vulnerability assessments. These variables primarily reflect the inundation potential for coastal areas. Mean wave height and significant wave height both represent a proxy for wave energy; often one or the other was included in the assessments.

Gornitz (1990) and Thieler and Hammar-Klose (1999) both developed extensive coastal vulnerability assessments along the U.S. Atlantic, Pacific, and Gulf coasts focused on geologic and physical vulnerabilities. Thieler and Hammar-Klose (1999) provided an update to the geologic and physical variables utilized in Gornitz (1990). These seminal U.S. coastal vulnerability assessment efforts continue to influence coastal vulnerability research. As such, many coastal vulnerability assessments utilize the same variables. This is evident in the geologic and physical variables that are most often used in coastal vulnerability assessments (Tables 2-4).

A ranking factor was applied to each variable prior to calculating the coastal vulnerability for each assessment. The rankings applied were 1 to 5 , where 1 was least vulnerable and 5 was most vulnerable (Gornitz 1991). These rankings were relative vulnerabilities and subject to scientific judgement (Bridges et al. 2015). Interestingly, Gornitz et al. (1997) assigned coasts with high tidal ranges as highly vulnerable because strong tidal currents are associated with high tidal ranges. However, Theiler and Hammar-Klose (1999) argue that coastal areas with low tidal ranges are highly vulnerable because of the impact storms have on the coastal evolution of coastlines with low tidal ranges. Additionally, Theiler and Hammar-Klose (1999, 2000a, and 2000b) assigned different ranking values to coastal slope, relative sea level rise, and mean wave height for the Atlantic, Pacific, and Gulf coasts. This allowed identification of the relative vulnerability where dominance or scale of coastal processes were different regionally, but did not allow comparisons between coasts because the scales were different (Bridges et al. 2015). The normalization technique improves comparisons between case studies by converting variables to scaled (between $\mathrm{o}$ and 1) dimensionless variables (Balica et al. 2012).

Coastal vulnerability was calculated multiple ways, either by the product mean, square root of the product mean, the sum of products, or utilizing 
weighted variables of the variables of interest. The square root of the product mean was most often used (Table 1). The product mean, square root of the product mean, and the sum of products were developed and tested in Gornitz (1991). Although Gornitz (1991) suggested coastal vulnerability can be computed either using the sum or the product of the variables, the advantage of using the product is the expanded range of values (Rao et al. 2008). Calculations using weighted variables were found to be more responsive to differences in environmental factors (Rao et al. 2008). Weighting variables depends on the relative significance of the different variables (Rao et al. 2008); however, weight assignments are largely based on best scientific judgment. Finally, Monnereau et al. (2017) demonstrate that different methodologies for quantifying vulnerability can yield widely different results, with significant implications for decision making.

Visualization platforms have more recently been incorporated into coastal vulnerability assessments. The incorporation of coastal vulnerability assessments into ArcGIS offers several advantages. These advantages include the following: recognizing patterns, combining multiple vulnerabilities effects (e.g., geologic and physical vulnerabilities) and visualizing these combined effects along coastlines (Sahoo and Bhaskaran 2018).

Although coastal vulnerability assessments are improving through more frequent considerations of the effects of multiple vulnerabilities and platforms are improving visualization of coastal vulnerability, there remains significant challenges in developing and improving coastal vulnerability assessments. These challenges are associated with identifying which variables to include (Adger 2006; Wamsley et al. 2015), gathering data (Szlafstein and Sterr 2007), and incorporating socioeconomic vulnerabilities (McLaughlin et al. 2002). Criteria for selecting variables should consider the following:

- Is the variable measuring the intended driving factor of vulnerability (Barnett et al. 2008)?

- Have causal links been established between the measured variable and represented process (Ozyurt and Ergin 2010)?

- Are the interaction of multiple variables reflected in the outcome of the assessment (Adger 2006)? 
- Are the interaction of multiple variables masking the importance of other response variables (Cooper and McLaughlin 1998)?

Additional challenges associated with coastal vulnerability assessments are using variables that are comparable across time (Adger 2006; Wolters and Kuenzer 2015), location (Adger 2006), and scale (Pendleton et al. 2010a; Wamsley et al. 2015; Wolters and Kuenzer 2015). These challenges are reflected in the variety of variables considered in the assessments reviewed.

Sea level rise and increased erosion not only have significant impacts to coastal habitats, but also impact coastal populations and infrastructure. Klein and Nicholls (1999) identified three potential socioeconomic impacts. These impacts are the following:

- The direct loss of economic, ecological, cultural, and subsistence living from the loss of land, infrastructure, and coastal habitats,

- Increased flood risk to coastal populations, land, and infrastructure, and

- Other impacts, including water management, salt water intrusion, and interruptions to biological activities.

Despite the acknowledgement of the socioeconomic vulnerabilities of coastal areas and the importance of including socioeconomic vulnerability into assessments (Gornitz et al. 1993), socioeconomic variables are regularly excluded in coastal vulnerability assessments.

The exclusion of socioeconomic variables can limit the evaluation of vulnerable coastal systems (Harvey et al. 1999). In response, more assessments are being developed to include socioeconomic vulnerability; however, there are significant challenges associated with incorporating socioeconomic vulnerabilities into coastal vulnerability assessments. For instance, variables that incorporate human well-being and the relative and perceived human vulnerability need to be developed (Adger 2006). Additional challenges include changing human perceptions (McLaughlin et al. 2002), growth or decline in population, and building new infrastructure and abandonment of older structures (Thatcher et al. 2013). The dynamic nature of coastal and social processes often underestimates future coastal vulnerability (Thatcher et al. 2013). 
Finally, coastal vulnerability is frequently assessed to identify vulnerable coastal areas for coastal zone management and to prioritize restoration activities and resources (Thatcher et al. 2013). Strategies for linking vulnerable coastal areas with appropriate restoration techniques are, however, limited. Future studies will need to assess strategies for incorporating coastal vulnerability assessments with specific mechanisms that can be addressed through coastal restoration and protection. 


\section{Summary}

Coastal areas are dynamic systems, driven by coastal processes and human intervention. As such, coastal areas are vulnerable to a number of factors such as erosion and sea level rise. Coastal vulnerability assessments identify relative vulnerability with different regions. These assessments integrate geologic, physical, and, more often, socioeconomic vulnerabilities to appropriately identify vulnerable coastal areas. Coastal vulnerability assessments were reviewed to identify the purpose, study location, variable considered, and calculation of coastal vulnerability. The review identified thirteen common variables, across geologic, physical, and socioeconomic processes, and identified the square root of the product mean of variable(s) of interest as the most common calculation to determine the relative coastal vulnerability of coastal areas. Socioeconomic vulnerabilities were recognized as a critical component of assessment and are more often being included in coastal vulnerability assessments despite inherent difficulties in data collection. Coastal vulnerability assessments can identify vulnerable coastal areas for coastal zone management, and use of visualization platforms improve communication of the combined effects of vulnerability into a single resource. However, relating vulnerable coastal areas with appropriate restoration techniques is lacking and requires further research. 


\section{References}

Addo, K. A. 2013. Assessing coastal vulnerability index to climate change: The case of Accra-Ghana. Journal of Coastal Research 165:1892-1897. https://doi.org/10.2112/SI65-320.1.

Adger, W. N. 2006. Vulnerability. Global Environmental Change. 16(3): 268-281. https://doi.org/10.1016/j.gloenvcha.2006.02.006.

Arkema, K. K., G. Gaunnel, G. Verutes, S. A. Wood, A. Guerry, M. Ruckelhaus, P. Kareiva, M. Lacayo, and J. M. Silver. 2013. Coastal habitats shield people and property from sea-level rise and storms. Nature Climate Change 3:913-918. Doi: 10.1038/NCLIMATE1944.

Aven, T. 2011. On some recent definitions and analysis frameworks for risk, vulnerability, and resilience. Risk Analysis 31(4): 515-522. doi:10.1111/i.1539-6924.2010.01528.x.

Bahinipati, C. S. 2014. Assessment of vulnerability to cyclones and floods in Odisha, India: A district-level analysis. Current Science 107(1):1997-2007.

Balica, S. F., N. G Wright, and F. van der Meulen. 2012. A flood vulnerability index for coastal cities and its use in assessing climate change impacts. Natural Hazards 64(1):73-105.

Barnett, J., S. Lambert, and I. Fry. 2008. The hazards of indicators: Insights from the environmental vulnerability index. Annals of the Association of American Geographers 98(1):102-119. http://dx.doi.org/10.1080/00045600701734315.

Baustian, J. J., I. A. Mendelssohn, and M. W. Hester. 2012. Vegetation's importance in regulating surface elevation in a coastal salt marsh facing elevated rates of sea level rise. Global Change Biology 18(11):3377-3382. https://doi.org/10.1111/i.13652486.2012.02792.x.

Boesch, D. F and R. E. Turner. 1984. Dependence of fishery species on salt marshes: The role of food and refuge. Estuaries 7(4):460-468.

Boruff, B. C. Emrich, and S. L. Cutter. Erosion hazard vulnerability of US coastal counties. Journal of Coastal Research 21(5):932-942. https://doi.org/10.2112/040172.1.

Bridges, T. S., P. W. Wagner, K. A. Burks-Copes, M .E. Bates, Z. A. Collier, C. J. Fischenich, J. Z. Gailani, L. D. Leuck, C. D. Piercy, J. D. Rosati, E. J. Russo, D. J. Shafer, B. C. Suedel, E. A. Vuxton, and T. V. Wamsley. 2015. Use of Natural and Nature-Based Features (NNBF) for Coastal Resilience. ERDC SR-15-1. Vicksburg, MS: US Army Engineer Research and Development Center.

Burkett, V. R. and M. A.Davidson. 2012. Coastal Impacts, Adaptation and Vulnerability. Island Press. 
Cahoon, D. R., P. F. Hensel, T. Spencer, D. J. Reed, K. L. McKee, and N. Saintilan. 2006. Coastal wetland vulnerability to relative sea-level rise: Wetland elevation trends and process controls. In Wetlands and Natural Resource Management. Berlin, GE: Springer.

Capobianco, M., H. J. DeVriend, R. J. Nicholls, and M. J. F. Stive. 1999. Coastal area impact and vulnerability assessment: The point of view of a morphodynamic modeler. Journal of Coastal Research 15(3):701-716.

Cooper, J. A. G., and S. McLaughlin. 1998. Contemporary multidisciplinary approaches to coastal classification and environmental risk analysis. Journal of Coastal Research 14(2):512-524.

Cutter, S. L., B. J. Boruff, and W. L. Shirley. 2003. Social vulnerability to environmental hazards. Social Science Quarterly 84(2):242-261. https://doi.org/10.1111/1540$\underline{6237.8402002 .}$.

Daniels, R. C., V. M. Gornitz, A. J. Mehta, L. Say-Chong, and R. M. Cushman. 1992. Adapting to sea-level rise in the U.S. Southeast: The influence of built infrastructure and biophysical factors on the inundation of coastal areas. ORNL/CDIAC-54. Oak Ridge, Tennessee: Environmental Science Division, U.S. Department of Energy.

Day, J. W., G. P. Kemp, D. J. Reed, D. R. Cahoon, R. M. Boumans, J. M. Suhayda, and R. Gambrell. 2011. Vegetation death and rapid loss of surface elevation in two contrasting Mississippi delta salt marshes: The role of sedimentation, autocompaction, and sea-level rise. Ecological Engineering 37(2):229-240. https://doi.org/10.1016/i.ecoleng.2010.11.021.

Day, J. W., Jr., D. F. Boesch, E. J. Clairain, G. P. Kemp, S. B. Laska, W. J. Mitsch, K. Orth, H. Mashriqui, D. J. Reed, L. Shabman, C. S. Simenstad, B. J. Streever, R. R. Twilley, C. C. Watson, J. T. Wells, D. F. Whigham. 2007. Restoration of the Mississippi Delta: Lessons from Hurricanes Katrina and Rita. Science 315(5819):1679-1684.

Diez, P. G., G. M. E. Perillo, and M. C. Piccolo. 2007. Vulnerability to sea-level rise on the coast of the Buenos Aires Province. Journal of Coastal Research 23(1):119-126.

Doukakis, E. 2005a. Identifying coastal vulnerability due to climate changes. Journal of Marine Environmental Engineering 8(2):155-160.

Doukakis, E. 2005b. Coastal vulnerability and risk parameters. European Water. 11(12):3-7.

Gaki-Papanastassiou, K., E. Karymbalis, S. E. Poulos, A. Seni, and C. Zouva. 2010. Coastal vulnerability assessment to sea-level rise based on geomorphological and oceanographic parameters: The case of Argolikos Gulf, Peloponnese, Greece.

Hellenic Journal of Geosciences 45(45):109-122.

Ganju, N. K., M. L. Kirwan, P. J. Dickhudt, G. R. Guntenspergen, D. R. Cahoon, and K. D. Kroeger. 2015. Sediment transport-based metrics of wetland stability.

Geophysical Research Letters 42:7992-8000. 
Gornitz, V.Z. 1990. Vulnerability of the East Coast, U.S.A. to future sea-level rise. In Proceedings of the Skagen Symposium. Journal of Coastal Research Special Issue No. 9:201-237.

Gornitz, V. M. 1991. Development of a Global Coastal Hazards Database: Annual Technical Report. Oak Ridge, TN: Oak Ridge National Laboratory.

Gornitz, V. M., T. W. White, and R. M. Cushman. 1991. Vulnerability of the U.S. to future sea-level rise. CONF-910780-1ON: DE91007853. Oak Ridge, TN: Oak Ridge National Laboratory.

Gornitz V., R. C. Daniels, T. W. White, and K. R. Birdwell. 1993. The development of a coastal risk assessment database: vulnerability to sea-level rise in the U.S. southeast. DE-ACo5-84OR21400, U.S. Government Report, Oak Ridge National Laboratory, Tennessee.

Gornitz, V. M., R. C. Daniels, T. W. White, and K. R. Birdwell. 1994. The development of a coastal risk assessment database: Vulnerability to sea-level rise in the U.S. Southeast. Journal of Coastal Research Special Issue 12:327-338.

Gornitz, V. M., and T. W. White. 1992. A Coastal Hazards Database for the U.S. East Coast. Report to the US Department of Energy. ORNL/CDIAC-45, NDP-043A. Oak Ridge, TN: Oak Ridge National Laboratory.

Gornitz, V. M. and T.W. White. 1994. A Coastal Hazards Database for the U.S. East Coast. Report to the US Department of Energy. ORNL/CDIAC-45, NDP-043B. Oak Ridge, TN: Oak Ridge National Laboratory.

Gornitz, V. M., T. W. Beaty, and R. C. Daniels. 1997. A Coastal Hazard Database for U.S. West Coast. Oak Ridge, Tennessee: Environmental Science Division, U.S. Department of Energy ORNL/CDIAC-81 NDP-043C, 147 p. Oak Ridge, TN: Oak Ridge National Laboratory.

Green, C. and L. McFadden. 2007. Coastal vulnerability as discourse about meanings and values. Journal Risk Research 10(8):1027-1045.

Harvey, N., E. Clouston, P. and Carvalho. 1999. Improving coastal vulnerability assessment methodologies for integrated coastal zone management: an approach from South Australia. Geographical Research 37(1):50-69. https://doi.org/10.1111/1467-8470.00065l.

Hauser, S., M. S. Meixler, and M. Laba. 2015. Quantification of impacts and ecosystem services loss in New Jersey coastal wetlands due to Hurricane Sandy storm surge. Wetlands 35:1137-1148.

Heberger, M., H. Cooley, P. Herrera, P.H. Gleick, and E. Moore. 2009. The Impacts of Sea-level Rise on the California Coast. CEC-500-2009-024-F. Sacramento, CA: California Climate Change Center.

Hedge, A. V., and V.R. Reju. 2007. Development of coastal vulnerability index for Mangalore Coast, India. Coastal Research 23(5):1106-1111. https://doi.org/10.2112/04-0259.1 
Hinkel, J., and R. J. T. Klein. 2009. Integrating knowledge to assess coastal vulnerability to sea-level rise: The development of the DIVA tool. Global Environmental Change 19(3):384-395.

Intergovernmental Panel on Climate Change - Coastal Zone Management Subgroup (IPCC CZMS). 1992. A common methodology for assessing vulnerability to sea level rise. 2nd revision. In: Global Climate Change and the Rising Challenge of the Sea. The Hague, The Netherlands: IPCC CZMS.

Intergovernmental Panel on Climate Change (IPCC). 2001a. Climate change 2001: Coastal Zones and Marine Ecosystems. Contribution of Working Group II to the Third Assessment Report of the IPCC. Cambridge, UK: Cambridge University Press.

Intergovernmental Panel on Climate Change (IPCC). 2001b. Climate change 2001: Impacts, Adaptation, and Vulnerability. Contribution of Working Group II to the Third Assessment Report of the IPCC. Cambridge, UK: Cambridge University Press.

Kirwan, M. L., G. R. Guntenspergen, A. D’Alpaos, J. T. Morris, S. M. Mudd, and S. Temmerman. 2010. Limits on the adaptability of coastal marshes to rising sea level. Geophysical Research Letters 37(23):L23401. https://doi.org/10.1029/2010GL045489/.

Kirwan, M. L., S. Timmerman, E. E. Skeehan, G. R. Guntenspergen, and S. Fagherazzi. 2016. Overestimation of marsh vulnerability to sea level rise. Nature Climate Change 6:253-260.

Klein, R. J. T., M. J. Smit, H. Goosen, and C. H. Hulsbergen. 1998. Resilience and vulnerability: Coastal dynamics or Dutch dikes? The Geographical Journal 164:259-268.

Klein, R. J. T., and J. R. Nicholls. 1999. Assessment of coastal vulnerability to climate change. Ambio 28(2):182-187. https://www.jstor.org/stable/4314873.

Kolker, A. S., M. A. Allison, and S. Hameed. 2011. An evaluation of subsidence rates and sea-level variability in the northern Gulf of Mexico. Geophysical Research Letters 38(21):L21404. https://doi.org/10.1029/2011GL049458|

Kumar, A. A., and P. D. Kunte. 2012. Coastal vulnerability assessment for Chennai, east coast of India using geospatial techniques. Natural Hazards 64(1):853-872.

Kumar, T. S., R.S. Mehendra, S. Nayak, K. Radhakrishnan, and K.C. Sahu. 2010. Coastal vulnerability assessment for Orissa State, East Coast of India. Journal of Coastal Research 26(3):523-534.

Mariotti, G., and S. Fagherazzi. 2013. Critical width of tidal flats triggers marsh collapse in the absence of sea-level rise. In Proceedings of the National Academy of Sciences of the United States of America (PNAS) 10(14):5353-5356. https://doi.org/10.1073/pnas.1219600110.

McLaughlin, S. and J. A. G. Cooper. 2010. A multi-scale coastal vulnerability index: A tool for coastal managers? Environmental Hazards 9(3):233-248. 
McLaughlin, S., J. McKenna, and J. A. G. Cooper. 2002. Socio-economic data in coastal vulnerability indices: Constraints and opportunities. Journal of Coastal Research 36:487-497. https://doi.org/10.2112/1551-5036-36.sp1.487.

Mendelssohn, I. A. and K. L. McKee. 1988. Spartina alterniflora die-back in Lousiana: Time-course investigation of soil. Journal of Ecology 76(2):509-521.

Monnereau I., R. Mahon, P. McConney, L. Nurse, R. Turner, and H. Vallès. 2017. The impact of methodological choices on the outcome of national-level climate change vulnerability assessments: An example from the global fisheries sector. Fish and Fisheries 18(4):717-731. https://doi.org/10.1111/faf.12299.

Mudd, S. 2011. The life and death of salt marshes in response to anthropogenic disturbance of sediment supply. Geology 39(5):511-512. https://doi.org/10.1130/focus052011.1.

Nicholls, R. J. 2003. Case study on sea-level rise impacts. ENV/EPOC/GSP(2003)9/FINA. In Organization for Economic Co-operation and Development (OECD) Workshop on the Benefits of Climate Policy: Improving Information for Policy Makers 9(69-86).

Nicholls, R. J. and A. Cazenave. 2010. Sea-level rise and its impact on coastal zones. Science 328(5985):1517-1520.

Nicholls, R. J., P.P. Wong, V. Burkett, C. D. Woodroffe, and J. Hay. 2008. Climate change and coastal vulnerability assessment: Scenarios for integrated assessment. Sustainability Science 3(1):89-102.

Ozyurt, G., and A. Ergin. 2010. Improving coastal vulnerability assessments to sea-level rise: A new indicator-based methodology for decision makers. Journal of Coastal Research 26(2):265-273. https://doi.org/10.2112/08-1055.1.

Paolo, G. D., J. Inglesias, G. Rodriguez, G. Benassai, P. Aucelli, and G. Pappone. 2001. Estimating coastal vulnerability in a meso-tidal beach by means of quantitative and semi-quantitative methodologies. Journal of Coastal Research 61:303-308. https://doi.org/10.2112/SI61-001.30.

Pendleton, E. A., R. E. Thieler, and S. J. Williams. 2010a. Importance of coastal change variables in determining vulnerability to sea- and lake-level change. Journal of Coastal Research 26(1):176-183. https://doi.org/10.2112/08-1102.1.

Pendleton, E. A., J. A. Barras, S. J. Williams, and D. C. Twichell. 2010b. Coastal Vulnerability Assessment of the Northern Gulf of Mexico to Sea-Level Rise and Coastal Change. U.S. Geological Survey Open-File Report 20101146.Washington, DC: U.S. Geological Survey (USGS) http://pubs.usgs.gov/of/2010/1146/.

Rani, N. N. V. S., A.N.V. Satyanarayana, and P.K. Bhaskaran. 2015. Coastal vulnerability assessment studies over India: A review. Natural Hazards 77(1):405-428.

Rao, K. N., P. Subraelu, T. V. Rao, B. H, Malini, R. Ratheesh, S. Bhattacharya, A. S. Rajawat, and Ajai. 2008. Sea-level rise and coastal vulnerability: An assessment of Andhra Pradesh coast, India through remote sensing and GIS. Journal Coastal Conservation 12(4):195-207. 
Reed, D. J. 2002. Sea-level rise and coastal marsh sustainability: Geological and ecological factors in the Mississippi delta plain. Geomorphology 48:233-243.

Romieu, E., T. Welle, S. Schneiderbauer, M. Pelling, C. Vinchon. 2010. Vulnerability assessment within climate change and natural hazard contexts: Revealing gaps and synergies through coastal applications. Sustainability Science 5(2):159-170.

Sahoo, B. and P. K. Bhaskaran. 2018. Multi-hazard risk assessment of coastal vulnerability from tropical cyclones- A GIS based approach for the Odisha coast. Journal of Environmental Management 206:1116-1178. https://doi.org/10.1016/i.jenvman.2017.10.075.

Smith, S. M., K.C. Medeiros, and M.C. Tyrrell. 2012. Hydrology, herbivory, and the decline of Spartina patens (Aiton) Muhl. in outer Cape Cod salt marshes (Massachusetts, USA). Journal of Coastal Research 28(3)3:602-612. https://doi.org/10.2112/JCOASTRES-D-10-00175.1.

Stagg, C. L. and I. A. Mendelssohn. 2010. Restoring ecological function to a submerged salt marsh. Restoration Ecology 18(s1):10-17. https://doi.org/10.1111/i.1526100X.2010.00718.x.

Szlafstein, C. and H. Sterr. 2007. A GIS-based vulnerability assessment of coastal natural hazards, state of Para, Brazil. Journal of Coastal Conservation 11:53-66.

Thatcher, C. A, J. C. Brock, and E. A. Pendleton. 2013. Economic vulnerability to sea-level rise along the northern U.S. Gulf coast. Journal of Coastal Research 63:234-243. https://doi.org/10.2112/SI63-017.1.

Thieler, E. R., and E. Hammar-Klose. 1999. National assessment of coastal vulnerability to sea level rise. Preliminary results for U.S. Atlantic Coast. Open-file report 99593. Reston, VA: http://pubs.usgs.gov/of/1999/of99-593/index.html.

Thieler, E. R., and E. Hammar-Klose. 2000a. National assessment of coastal vulnerability to sea level rise. Preliminary results for U.S. Atlantic Coast. Open-File Report oo178. Reston, VA: U.S. Geological Survey (USGS). http://pubs.usgs.gov/of/of00-178/.

Thieler, E. R., and E. Hammar-Klose. 200ob. National assessment of coastal vulnerability to sea level rise. Preliminary results for the U.S. Gulf of Mexico Coast. Open-File Report 00-179. Reston, VA: U.S. Geological Survey (USGS). http://pubs.usgs.gov/of/of00-179/.

Turner, R. E. 1997. Wetland loss in the northern Gulf of Mexico: Multiple working hypotheses. Estuaries 20(1):1-13.

Wamsely, T. V., Z. A. Collier, K. Brodie, L. M. Dunkin, D. Raff, and J. D. Rosati. 2015. Guidance for developing coastal vulnerability metrics. Journal of Coastal Research 31:1521-1530. https://doi.org/10.2112/JCOASTRES-D-14-00015.1.

Williams, A. T. P. Davis, R. Curr, A. Koh, J. Cl. Bodere, B. Hallegouet, C. Meur, and C. Yoni. 1993. A checklist assessment of dune vulnerability and protection on Devon and Cornwall, UK. Coastal Zone'93 3394-3408. 
Wolters, M. L. and C. J. Kuenzer. 2015. Vulnerability assessments of coastal river deltas categorization and review. Journal of Coastal Conservation 19(3):345-368. https://doi.org/10.1007/s11852-015-0396-6.

Yin, J., Z. Yin, J. Wang, and S. Xu. 2012. National assessment of coastal vulnerability to sea-level rise for the Chinese coast. Journal of Coastal Conservation 16(1):123133 .

Zervas, C. 2009. Sea Level Variations of the United States 1854-2006. NOS CO-OPS 053. Silver Spring, MD: Center for Operational Oceanographic Products and Services, National Ocean Service (NOS), National Oceanic and Atmospheric Administration (NOAA). 


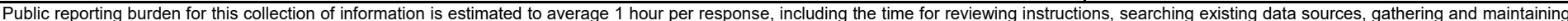

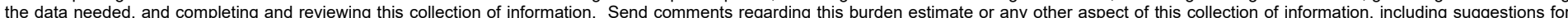

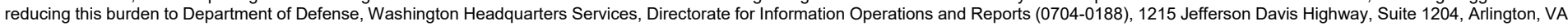

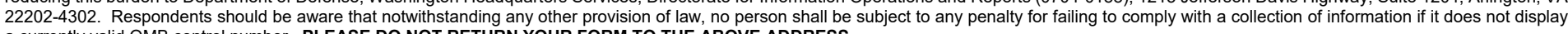
a currently valid OMB control number. PLEASE DO NOT RETURN YOUR FORM TO THE ABOVE ADDRESS.
1. REPORT DATE (DD-MM-YYYY)
2. REPORT TYPE
3. DATES COVERED (From - To)

June 2019

Final report

4. TITLE AND SUBTITLE

A Review of Coastal Vulnerability Assessments: Definitions, Components, and Variables

\section{AUTHOR(S)}

Christine VanZomeren and Damarys Acevedo-Mackey

5a. CONTRACT NUMBER

5b. GRANT NUMBER

5c. PROGRAM ELEMENT NUMBER

5d. PROJECT NUMBER

2016-ER-5

5e. TASK NUMBER

5f. WORK UNIT NUMBER

7. PERFORMING ORGANIZATION NAME(S) AND ADDRESS(ES)

8. PERFORMING ORGANIZATION REPORT NUMBER

U.S. Army Engineer Research and Development Center

Environmental Laboratory

ERDC/EL SR-19-5

3909 Halls Ferry Road, Vicksburg, MS 39180-6199

9. SPONSORING / MONITORING AGENCY NAME(S) AND ADDRESS(ES)

10. SPONSOR/MONITOR'S ACRONYM(S)

Headquarters, U.S. Army Corps of Engineers

Washington, DC 20314-1000

11. SPONSOR/MONITOR'S REPORT

NUMBER(S)

\section{DISTRIBUTION / AVAILABILITY STATEMENT}

Approved for public release; distribution unlimited.

\section{SUPPLEMENTARY NOTES}

\section{ABSTRACT}

Coastal zones are dynamic environmental systems providing an interface between land and sea. Coastal zones are also dynamic socioeconomic systems that support concentrated populations and critical infrastructure. Coastal features provide an array of ecological services including wildlife habitat, carbon sequestration, water filtration, erosion protection, and storm/flood protection. Provision of these services is dependent upon the resiliency of these vulnerable coastal environments to climate change, and changes in sea level and storm frequency/intensity. This report summarizes coastal vulnerability assessments based on peer-reviewed journal articles and published reports. Topics addressed include (1) an introduction to coastal vulnerability, (2) factors contributing to coastal vulnerability, (3) a review and synthesis of coastal vulnerability assessment methods, and (4) knowledge gaps and opportunities for additional research. The variables most commonly used for vulnerability assessments are reduced to 13 variables that apply across geologic, physical, and socioeconomic processes. Approaches for developing a coastal vulnerability assessment are reviewed, and an approach based on a calculation of the square root of the product mean of variable(s) of interest is the most commonly used assessment technique. Socioeconomic vulnerability is recognized as a critical component of vulnerability assessments that is often excluded because of inherent difficulties in data collection.

15. SUBJECT TERMS

\section{Coastal zone management \\ Coastal engineering \\ Coasts}

\section{Climatic changes}

Sea level

\section{SECURITY CLASSIFICATION OF:}

a. REPORT

UNCLASSIFIED

b. ABSTRACT
UNCLASSIFIED

c. THIS PAGE

UNCLASSIFIED
17. LIMITATION OF ABSTRACT 18. NUMBER
OF PAGES

46 19a. NAME OF RESPONSIBLE PERSON

19b. TELEPHONE NUMBER (include area code) 